\title{
Dramatiseret museumsformidling
}

\section{Når publikums deltagelse får betydning}

\author{
INGRID VATNE
}

Title: Dramatized museum mediation and the meaning making process

\begin{abstract}
Audience participation is playing an important role in museum mediation at living history museums around the world. The aspect of participation is challenging the traditional concept of meaning making, and I will demonstrate the need for new conceptual tools for dealing with the meaning making issue in a way that enhances participation as a method for meaning making in living history museums. Building on the theoretical framework of enunciation theory and the method of participative observation back in 2008-11, when I was researching mediation in the open-air museum Den Gamle By in Aarhus, Denmark, it is my ambition to contribute to the development of the conceptual tools for dealing with the issue of audience participation in a way that emphasizes new goals for mediation.
\end{abstract}

Keywords: Dramatized mediation, living history, audience participation, identity of participation, authenticity.

Dramatiserende virkemidler er ikke nyt i historieformidling til publikum. Frilandsmuseerne har en over hundrede år lang tradition for at integrere teatrale teknikker i udstillinger og anden form for formidling (Rasmussen 1993, Brenna 1999, Maure 2004, Skougaard 2005, Rentzhog 2007). I lige så lang tid har formidlingen på frilandsmuseerne været genstand for kritik - en kritik som især har fremhævet, at en manglende skelnen mellem begreberne fortid og historie er deres grundlæggende problem (Bloch 1930/1993:75). Den franske historiker og leder for Annales-skolen Marc Bloch påpegede i sin tid, at til trods for at frilandsmu- seerne (som han betegner som tekniske museer) er lærerige, så har de en brist: "Konsten att klassificera och datera redskabsformer har av den förhistoriska arkeologin bragts till en sällsynt fulländning. Men medeltidsarkeologin, liksom det historiska föremålsstudiet, är nästan enbart estetisk" (Bloch 1930/1993:75). Frilandsmuseerne ser, ifølge Bloch, alle objekter som et grundlag til at skabe atmosfære frem for at skabe mulighed for, at publikum kan undersøge objekterne ud fra et mere teoretisk udgangspunkt. Ca. 70 år efter Blochs udtalelse fremhæver Gavin Baldwin og Beth Goodacre en lignende "brist", når de betragter 


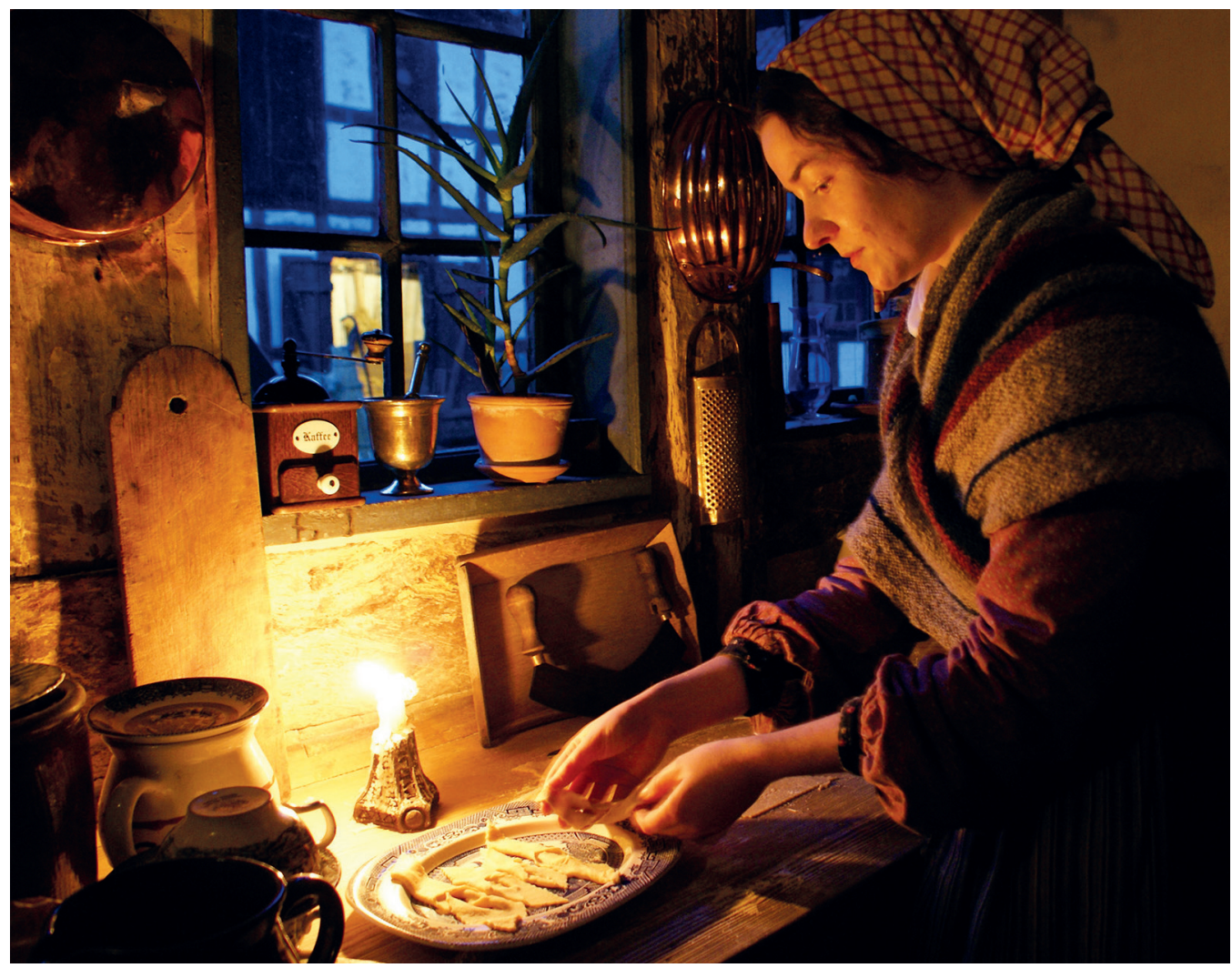

Fig. 1. Tjenestepige i købmandsgårdens køkken. Foto: Den Gamle By, 2008.

frilandsmuseernes formidling ud fra et historie-pædagogisk udgangspunkt. De fremhæver også skelnen mellem fortid og historie. Fortid refererer, ifølge Baldwin og Goodacre, til den historiske fortid, således som den faktisk forløb, og historie refererer til den fortælling, som konstrueres i formidlingssammenhæng på baggrund af spor fra fortiden (Goodacre \& Baldwin 2002:9). Nærværende artikel foreslår, at man ser problematikken mellem fortid og historie som knyttet til spørgsmål om valg af objektiv: Fortid karakteriseres af et faktuelt historiefagligt orienteret objektiv, og historie karakteriseres af et modtagerorienteret objek- tiv, hvor fokus er på publikums møde med fortiden.

\section{LEVENDEGØRELSE - INDHOLD OG METODE}

Begrebet living history knyttes til den formidlingstradition, som voksede frem i 1960'erne på de amerikanske frilandsmuseer, hvor hensigten var at gøre historien levende for publikum. En af pionererne inden for forskning i living history er folklorist Jay Anderson. Han ser living history som en formidlingsmetode, hvor publikum kan opnå en særlig erfaring skabt ud 
114 fra de historiske rammer. Erfaringen giver dermed mulighed for at opleve historiens tekstur i kraft af, at alle sanser involveres (Anderson 1986). Living history har som formidlingsmetode altså publikums oplevelse af og erfaring med historien som sit fokus i budskabet. På den måde kan man sige, at metoden er modtagerorienteret i forhold til formålet. I Danmark har begrebet levendegørelse været den mest almindelige betegnelse for den formidlingspraksis, som knyttes til det amerikanske begreb living history. Jeg vil argumentere for, at levendegørelse som formidlingsmetode kan referere både til viden om fortiden og til erfaring med fortiden, og at formålet kan ses i sammenhæng med publikums deltagelse. Ved at anvende begrebet dramatiseret museumsformidling fremhæver jeg, at publikums erfaringsdannelse anses som betydningsgivende for formidlingens formål. Jeg vil argumentere for, at der er behov for at gentænke opfattelsen af formidlingens formål på en måde, som tager højde for, at formidlingsbudskabet kan have forskellig karakter. Formidlingsbudskabets karakter, som det skabes i en formidlingssituation, er afhængig af den måde, hvorpå publikum aktiveres i formidlingsrummet. Ved at tage udgangspunkt $\mathrm{i}$ casemateriale fra Den Gamle By i Aarhus, hvor jeg foretog deltagerobservation i forbindelse med ph.d.-projekt i perioden 2008-2011 (Vatne 2013), spørger jeg her, hvordan publikums erfaring får betydning gennem deltagelse.

\section{Den Gamle By og leVEnde museum}

Begrebet levende museum er Den Gamle Bys betegnelse for living history (Ravn 2001:7). I Den Gamle By bruges begrebet om formidling, hvor formidlere anvender førstepersons fortolkning. Det vil sige, at formidlerne er i dragt og rolle og levendegør historiske miljøer gennem handling, fortælling og dialog med de besøgende. Museets hensigt med formidlingsformen er at gestalte historiske idealtyper, det vil sige at materialisere forestillingen om personer, som kunne have levet i 1800-tallet, gennem formidling i dragt og rolle. For at gestalte de historiske idealtyper er der skabt en identitet, en rolle og en funktion til hver af karaktererne, som publikum møder i formidlingen. Derudover henviser begrebet til forskellige andre metoder, som benyttes for at "formidle det liv, der blev levet, og som er forsvundet med menneskerne" (Ravn 2000:37). Herindunder hører blandt andet detaljer i miljøet, lyde, lugte og smag, ild og varme. Intentionen er at gøre historien nærværende for publikum ved at sætte fokus på det historiske menneske, på fortællingen og på de historiske helheder (Ravn 2002:117). Jeg vil i det følgende fremhæve to formidlingssituationer fra mit feltarbejde i Den Gamle By. Jeg har valgt at vægte de sanselige aspekter i formidlingssituationen og den måde, hvorpå publikum responderer herpå. Den første formidlingssituation foregår i købmandsgårdens køkken, hvor to køkkenpiger er i gang med at tilberede mad på et støbejernskomfur. Den anden foregår i skomagermadammens hjem, hvor skomagermadammen har besvær med at tænde ild i husets ildsted. De to formidlingssituationer er bygget op med samme formål, at formidle livet i købstaden, og formidlingen følger samme udgangspunkt for opsætning og design, altså et fokus på at gestalte historiske idealtyper.

\section{KØBMANDSGÅRDENS KØKKEN}

"Så skal du selv vaske op og sådant noget," spørger en af museumsgæsterne, som står sammen med køkkenpigen i købmandsgårdens køkken, idet jeg lister mig ind ad køkkenvejen. Jeg stiller mig i varmen ved siden af komfuret og holder mig lidt i udkanten af den store grup- 


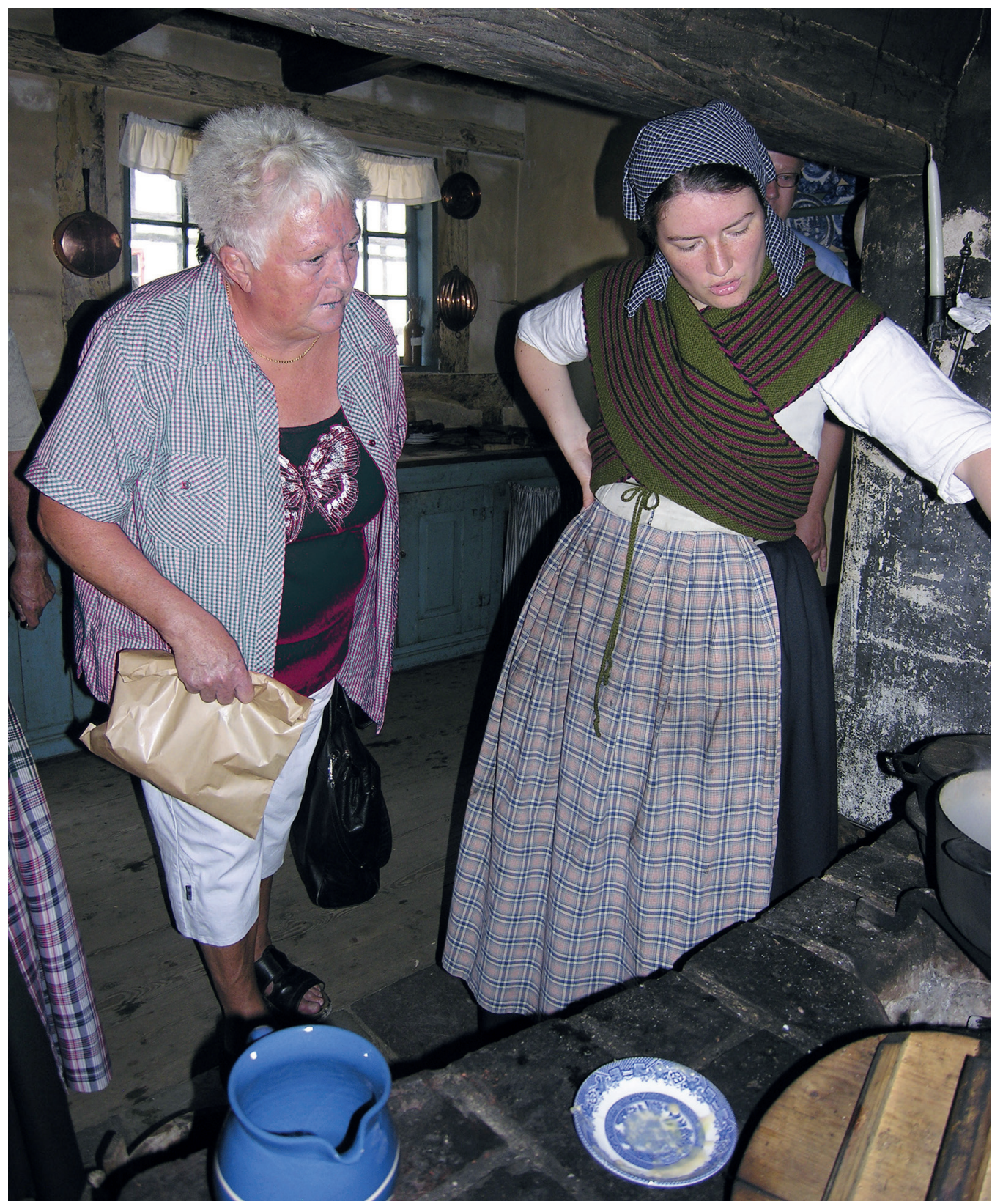

Fig. 2. Tjenestepige laver mad $i$ Købmandsgårdens køkken og forteller publikum om købmandens måltider. Foto: Den Gamle By, 2008. 
pe mennesker, som står i en rundkreds og taler med køkkenpigen, som rører i den store gryde. Der dufter af ild og varm kål. "Ja, nu er man jo så heldig, at man har fået to asylbørn i dag," forklarer køkkenpigen. "To piger henne fra asylet, som kan hjælpe til i køkkenet," fortsætter hun. "Får man det her i..." spørger en af gæsterne. ”Ja, her i 1864 er det almindeligt at man kan få noget hjælp fra børnene henne fra asylet. Så kommer de og hjælper et par timer. Så ser en jo efter, at de også får lidt at spise, så skal de jo ikke have så meget henne ved asylet," forklarer køkkenpigen. "Var folk mere lykkelig dengang," spørger en af gæsterne. "Ja, hun er da vældig tilfreds," svarer køkkenpigen, hvorefter hun proklamerer, at købmandsgården er det bedste sted i hele byen at tjene på. "Ja, hun får jo sin kost og logi, jo - og så får hun fem rigsdaler om måneden. Ja, her hos købmanden er det godt at tjene - og noget af det gode her hos købmanden er jo, at vi får kød til maden hver dag!" Køkkenpigen støtter sit udsagn med armbevægelser, inden hun placerer hænderne i siden. "Ja, muligvis hos borgmesteren," fortsætter hun, "borgmesteren er jo måske en finere mand end købmanden, men derfor er han jo ikke rigere. Men ellers er det ikke så mange steder her i byen, hvor man får spise kød til maden hver dag. Købmanden har jo også skibe." En af de besøgende spørger, om de somme tider får fisk. Det kan køkkenpigen bekræfte. Gæsterne taler lidt sammen. To asylpiger står henne ved køkkenbænken og kigger på. En af gæsterne spørger køkkenpigen, om det er skolestuen, der ligger i forlængelse af køkkenet? "Nej, det er skam ingen skolestue, da!" udbryder hun. "Det er da købmandens stuer." "Jamen helt nede i den anden ende, hvad er det der, da," spørger han videre og får at vide, det er købmandens store sal, gildesalen. "Det er jo der..., hvis der kommer fremmede til byen.... hvis I ser for enden af gildesalen, ser I kamme- ret, hvor der står to senge. Der overnatter folk, hvis de skal til byen og handle hos købmanden," forklarer køkkenpigen videre. Et hold udenlandske gæster kommer ind, idet de andre forlader køkkenet for at kigge nærmere på gildesalen. Køkkenpigen fortæller på engelsk om det sted, hvor gæsterne nu befinder sig. De to piger fra asylet bliver beordret til at servere $s ø$ bekål for gæsterne, mens kokkepigen forklarer, hvordan det er at arbejde for købmanden (Vatne 2013b:24).

I denne situation tager køkkenpigerne udgangspunkt i maden for at tegne et billede af det levede liv i købstaden, hvortil de perspektiverer købmandens sociale og økonomiske status igennem deres samtale med de besøgende. Formidlernes måde at indskrive sig selv i dette levede liv gør dem til en del af fortællingen om købstaden. Af den ovenfor beskrevne dialog fremgår, at der eksisterer to forskellige niveauer af "her og nu", hvor handling får betydning: fortællingens her og nu, hvortil formidlerne $\mathrm{i}$ dragt og rolle agerer i købstaden anno 1864, og de besøgendes her og nu, som placerer de besøgende som betragtende eller spørgende til fortællingen. Spørgsmål som eksempelvis "var folk mere lykkelig dengang" fremhæver, at publikum forstår sin egen handling som bundet til en nutid, der adskilles fra fortællingens nutid.

\section{SKOMAGERMADAMMENS HJEM}

Skomagermadammen rejser sig fra sin stol og går ind i det lille bitte køkken, hvor hun klager over, at det er svært at få tændt op i ilden i dag. "Nogle gange når det er rigtigt trunt i vejret, så..." "Så får ilden ikke rigtig fat?" fuldfører en af de besøgende, som står bag ved hende. "Nej, jeg ved ikke hvad det er, men den vil bare ikke rigtig," bekræfter skomagermadammen. Over de kæmpende gløder inde i den sorte røg, der 


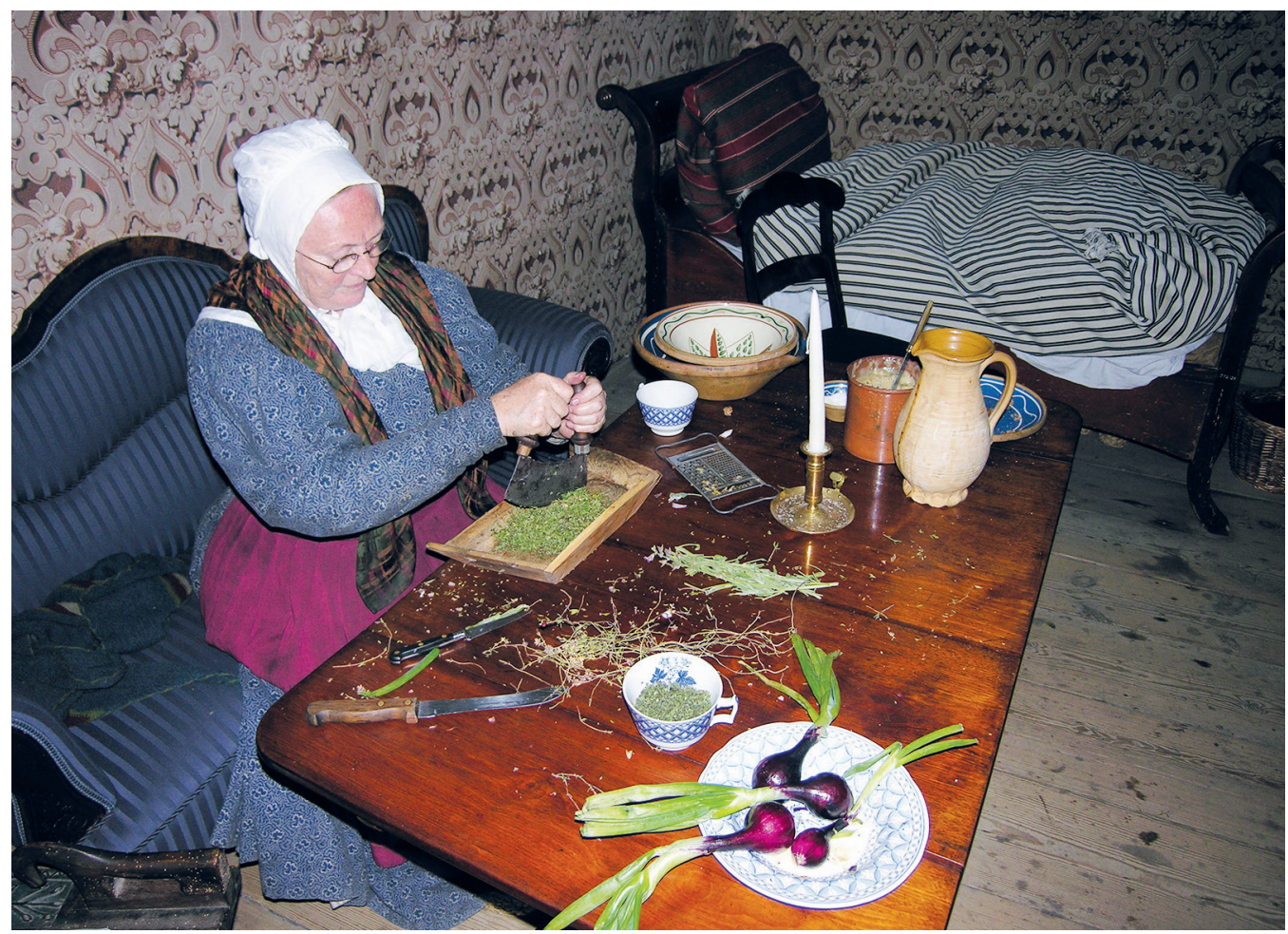

Fig. 3. Skomagermadammen laver krydderfedt. Foto: Den Gamle By, 2008.

stiger op fra ildstedet, står en stegepande på et stykke trekantet jern. Henvendt til de besøgende, der har stillet sig nysgerrigt rundt om hende for at se, forklarer hun med sin fynske accent: "Jeg vil have gang i min ild, for så kan jeg lave mig brød med lidt koriander og lidt vand, og så med sirup på, det er helt dejligt. Men jeg kan ikke få ild i dag." Hun vender sig mod ildstedet igen og roder med en jernpind i håb om at få gang i ilden. De besøgende kigger hende spændt over skulderen. "Ja, nu må vi se - om jeg overhovedet får noget mad i dag," siger skomagermadammen. Hun griner lidt, mens hun forsøger at bevæge sig mellem alle de besøgende og ind i stuen igen. "Men så kan man vel klare sig med en fedtemad eller to.
Kunne I tænke jer sådan en," spørger hun. Flere af de besøgende, alle midaldrende kvinder, vil gerne prøve. "Er det krydderfedt," spørger den ene. "Ja," svarer skomagermadammen, "ja, som jeg laver med æbler og stødt timian. Det kan jo ikke bare være fedt, jo. Det må gerne være lidt andet i. Vi skulle jo gerne holde os raske og friske." De besøgende sætter sig rundt om bordet og taler sammen om det, de smager, og om duften (Vatne 2013b:28).

Problemet med at få gang i ilden illustrerer én af skomagermadammens hverdagslige udfordringer, og herigennem skabes indgangen til hendes liv i købstaden. Til forskel fra dialogen i købmandsgårdens køkken taler publikum i nutid, når de kommunikerer med sko- 
magermadammen. Man kan måske sige, at det er gennem skomagermadammens handling gennem hendes udfordring med ilden, at publikums møde med historien skabes. En forskel kommer til syne i den måde, hvorpå publikum placerer sig selv i forhold til den handling, som udspiller sig i interaktionen mellem publikum og formidlerne i dragt og rolle. Publikum inddrages ved, at de både interagerer i skomagermadammens handling og samtidig fortolker på den betydning, handlingen får som historieformidling. I det følgende vil jeg fremlægge en udsigelsesteoretisk tilgang for at kunne italesætte den betydningsproduktion, der foregår i de to formidlingssituationer, jeg har præsenteret ovenfor.

\section{UDSIGELSESTEORI}

Udsigelsesteorien (enunciation theory) er udviklet med henblik på analyse af betydningsskabelse med udgangspunkt i den litterære tekst. Flere forskere har fundet teorien anvendelig til også at undersøge betydning i performative kommunikationsformer (Thygesen 2008, Aremark 2010). Således sidestilles dramateksten med den litterære tekst, og de udsigelsesteoretiske begreber bliver anvendelige til at udskille forskellige måder, hvorpå betydning skabes. Udsigelsesteori bygger på den franske sprogforsker Émile Benveniste og hans grundlæggende pointe $\mathrm{i}$ at skelne mellem sprogets semiotiske og semantiske niveauer. Det semiotiske niveau forstår betydning som en binær struktur bestående af en betydningsbærende form (le signifiant), der refererer til et betydningsindhold eller en referent (le signifié). Det semantiske niveau fremhæver betydning som noget, der produceres i den singulære kontekst, udsigelsesagten. Udsagnet som produceres gennem udsigelsesagten, karakteriseres af, at en afsender udtrykker noget til en modta- ger. Teorien skelner mellem den reelle læser og tekstens implicitte eller indfældede læser, altså en læserposition som etableres på et tekstligt niveau. Samtidig skelner den mellem den reelle fortæller og den implicitte fortæller, altså en fortæller, som optræder på tekstens niveau. Således skelnes der også mellem fortællingen/ tekstens her og nu og det reelle her og nu, hvor nogen læser teksten, eller hvor forfatteren skriver teksten. Udsagnets betydning er altid afhængig af de rammer, som definerer handlingens konkrete her og nu. Benveniste betegner handlingen som udsigelsen, og udsagnet får betydning gennem handlingen. Der kan foreligge flere handlinger, som påvirker betydningsdannelsen: Det at skrive en tekst er én handling, det at læse teksten er en anden handling. De to handlinger adskiller sig i tid. Men det at nogen skal læse teksten, indgår som et indbefattet handlingsniveau, når teksten produceres. Handlingerne er altså forbundet til hinanden betydningsmæssigt. Med begrebet udsagt udsigelse fremhæves de forskydninger, som ligger $i$, at en forfatter skriver en tekst i en kontekst, som adskiller sig fra den performerende udsigelse, altså akten hvor teksten realiseres gennem formidling. Alle handlingsaspekter er tilstede som betydningslag i udsigelsen, men der vil være forskel på, hvordan de forskellige handlinger betones og fremhæves som betydningsgivende.

I forhold til Den Gamle Bys levendegørelse vil man kunne forklare idealtyperne, eksempelvis skomagermadammen og den rollebeskrivelse, som foreligger for at kunne gestalte denne figur, som del af et miljø, som fikseret betydning (udsagt udsigelse). Det vil sige, at betydningen er fikseret i fremskrivelsen af idealfiguren som en person fra fortiden. Betydningen skabes i opbygningen af denne idealfigur set $i$ relation til den faktiske fortid, som idealfiguren som udtryk henviser til. Denne betydning 
er således implicit i teksten og uafhængig af det reelle publikums tilstedeværelse. Dog er det vigtig at pointere, at det fikserede ikke i sig selv udgør betydningen, men indgår som indfældet betydning, når teksten omsættes til dramatiseret museumsformidling. Når rollerne udspilles i interaktion med publikum, kan de forklares ud fra begrebet performerende udsigelse, altså med vægt på den betydning, som skabes i interaktion med publikum. Når det gælder om at undersøge publikumsdeltagelsens betydning, kan det være brugbart at differentiere mellem performerende udsigelse, hvor dramatiserede virkemidler anvendes for at inddrage publikum i historieformidling, og udsagt udsigelse, hvor forestillingen om det implicitte budskab er aktivt. Distinktionen fremhæuer, at betydning er et spørgsmål om rammesætning og kontekstualisering, og hvordan publikum deltager i formidlingssituationen.

Ved at anvende udsigelsesteorien på formidlingssituationen udskiller jeg to niveauer, hvorpå betydning skabes: Det ene niveau vægter den udsagte udsigelse, hvilket medfører, at budskabet knyttes til den reelle forfatter, der har indfældet betydning i teksten, og det er uafhængig af, hvem og hvordan teksten læses. Det andet niveau vægter den performerende udsigelse, hvor betydning skal findes i den måde, hvorpå udsigelsen bliver skabt i interaktion med publikum: det vil sige i kombination mellem iscenesættelsen af interiør, gestaltning af historisk figur gennem dragt og rolle og i interaktionen mellem deltagerne i formidlingsrummet. Jeg foreslår dette teoretiske redskab i forhold til museumsformidling således, at de to niveauer kan anses som virkende på samme tid, men hvor det ene niveau vil være mere fremtrædende end det andet, afhængig af den rolle publikums deltagelse har som del af budskabet. Med de udsigelsesteoretiske begreber i baghovedet vender jeg tilbage til mine cases fra henholdsvis købmandsgårdens køkken og 119 skomagermadammen.

Som tidligere fremhævet responderer publikum forskelligt på de to formidlingssituationer: I købmandsgårdens køkken stiller publikum spørgsmål, som knytter de gestaltede rollefigurer til de faktiske forhold i fortiden. $\mathrm{Mu}-$ seets tradition som dannelsesinstitution bliver fremtrædende og etablerer et fokus på museet som afsender eller forfatter til et budskab. Publikum søger den udsagte udsigelse som kilde til betydning, hvor denne knyttes til den pædagogiske og historiefaglige vinkel og fremhæver betydning som viden om. Publikums egen deltagelse bliver her at anskue som betragtere, hvor de befinder sig i den reelle nutid og skuer tilbage i fortiden. Eksempelvis ses dette, da én spørger, om det er almindelig at få asylpiger i den tidsperiode, som handlingen refererer til. Hos skomagermadammen responderer publikum anderledes på skomagermadammens handlinger og hendes måde at indtage rummet på, hvor hun inviterer publikum ind i sin dagligdag gennem udfordringen med ilden. Publikum kan genkende eller relatere sig til skomagermadammens udfordring med ilden. Når hun begynder at forklare, fuldfører publikum hendes sætning. Den måde hvorpå publikum træder ind i skomagermadammens rum, sætter sig ved bordet og bidrager gennem deltagelse til at skabe et foellesskab, gør det muligt at tale om, at betydningen vægtes i interaktionen frem for interaktionens henvisning til fortiden. Det er ikke fortcellingen om fællesskabet, der bliver budskabet. Det er snarere en produktion af fællesskabet, som noget der skabes gennem publikums deltagelse, der er budskabets betydningsbærende karakter. Hermed mener jeg, at vi har begreber til at kunne fremhæve forskellige måder, hvorpå publikums deltagelse får betydning: henholdsvis som betragtende/fortolkende og som aktive $i$ at producere/ 
fremskabe et særligt fællesskab. Med andre ord fremhæver denne skelnen forskellige positioner, som publikum kan indtage, når det handler om at deltage i formidlingen. Man kan stille spørgsmål om, hvorfor de to cases får forskellig karakter af betydning: Skal årsagen til den forskellige betydning tilskrives det mere abstrakte overordnede formidlingsdesign, forstået som dramateksten, og de valgte formidlingsmæssige greb? Eller skal årsagen tilskrives de tilstedeværende mennesker, som interagerer i den konkrete formidlingssituation? I forhold til udsigelsesteorien vil dette spørgsmål besvares med, at det er afhængig både af den indfældede betydning (udsagt udsigelse) og den performerende udsigelse, altså den konkrete formidlingssituation hvor publikum og formidlere mødes i det konkrete her og nu. Teorien ser netop hver singulær situation som betydningsskabende i sig selv. I den overværede situation hos skomagermadammen synes den performerende udsigelse som betydningsproduktion at vægte en invitation til publikum om at træde ind i skomagermadammens (tekstens indfældede) her og nu. Publikum accepterede og bidrog til produktion af fællesskabet som betydningsbærende budskab.

Ved at anvende udsigelsesteorien som forståelsesmodel for betydningsdannelse i dramatiseret museumsformidling kan man altså nuancere mellem forskellige måder, hvorpå publikums deltagelse får betydning. Hvad der skaber udsagnets betydning og karakter, er blandt andet afhængig af den position, som vægtes som afsender på et budskab, samt hvilken position publikum tildeles gennem den dramatiserede museumsformidling. Budskabet kan have karakter af at betyde noget i form af viden om. Men budskabet kan også have karakter af at betyde noget i form af deltagelsens tilnærmede materialitet, som eksempelvis det særlige fællesskab, som skabes når publi- kum og skomagermadammen sidder rundt bordet og spiser fedtemadder. Jeg har anvendt udsigelsesteoretiske begreber for at fremhæve, hvordan formidlingsbudskabet afhænger af den måde, hvorpå publikums deltagelse får betydning. Jeg vil i det følgende tage fat i den tidligere refererede problematik vedrørende fortid og historie med henblik på at fremhæve, hvordan de historiske idealtyper som formidlingsmæssigt greb er blevet kritiseret på baggrund af argumenter, som også kan ses i den hundredeår lange kritik af levendegørelse. Min ambition er i det følgende at gøre opmærksom på nødvendigheden af et begrebsapparat, som synliggør, at betydning i høj grad er afhængig af publikums deltagelse og den måde, hvorpå deltagelsesaspektet indgår som del af den udsagte udsigelse. Betydningsspørgsmålet kan ikke afklares ved at tage udgangspunkt i et tankesæt, hvor formidling forstås på baggrund af en mere traditionel tilgang til publikums rolle og til formidlingsformålet.

\section{IDEALTYPERNE OG VIDEN OM FORTIDEN}

Tager man udgangspunkt i den måde, hvorpå publikum spørger ind til historien i købmandsgården anes altså en tidsmæssig afstand. Publikum spørger ind til, hvordan det var i gamle dage, og formidlerne svarer, som var de en del af gamle dage. Betydningshandlingen vægter gengivelsen af den historiske fortid. Denne måde at fortolke betydning af formidlingen på svarer til den måde, hvorpå Den Gamle By forstår de historiske idealtypers kommunikative potentiale.

I Den Gamle Bys levende museum har museets fagfolk valgt at rekonstruere et antal idealtyper, altså personer som kunne have levet på et bestemt tidspunkt. De er udstyret med en identitet, en rolle og en funktion, som er med til at give deres fremtræden 


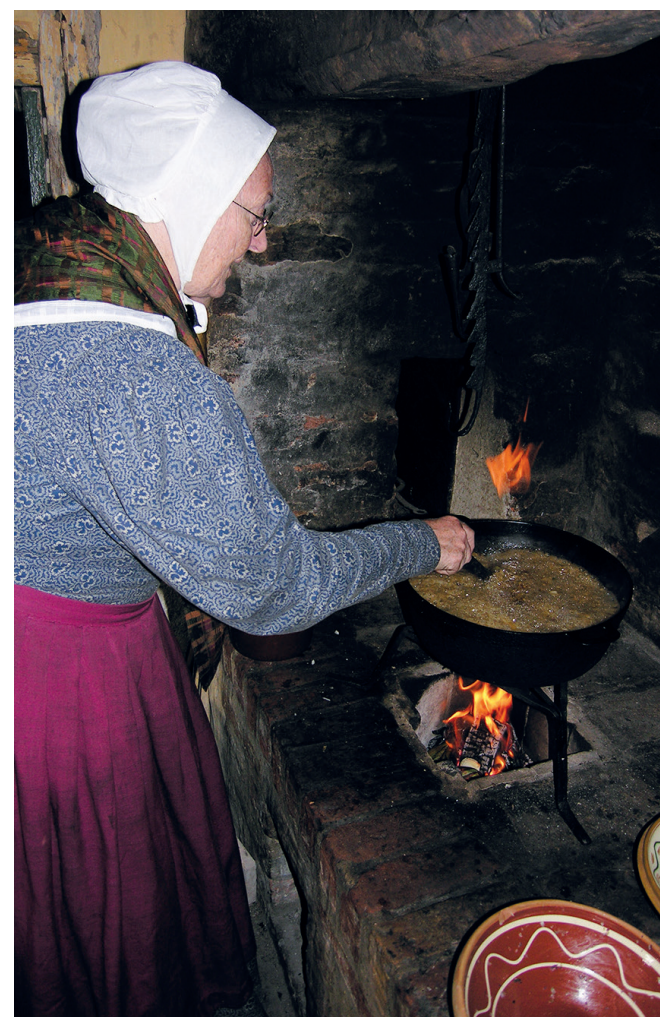

Fig. 4. Skomagermadammen har fået gang i ilden over kogestedet og laver krydderfedt. Foto: Den Gamle By, 2008.

dybde og dimension. Det er klart, at man ikke kan give aktørernes ansigter og kroppe det præg, som nød, sygdomme, undertrykkelse og krig må have sat på mange af dem (Ravn 2008:15ff.).

Set i forhold til Den Gamle Bys overordnede målsætning om at formidle købstadernes historie fungerer gestaltningerne af idealtyperne som det fortælleniveau, hvor fortidens mennesker og deres hverdag formidles. De gestaltede idealfigurer fremhæver "det levede liv" som budskab, og det formidles ved at etablere specifikke her-og-nu situationer, som formidles gennem levende museum. Blandt andet funge-

rer aktørernes sprog, beklædning, handlinger, adfærd og deres sociale rolle i de respektive miljøer som byggesten i de personificeringer, som gestaltes gennem levende museum. Ud over at kunne formidle gennem samtale med de besøgende spiller det en væsentlig rolle, at formidling også forstås på baggrund af den helhed, som etableres, når en person i en historisk dragt bevæger sig i et historisk miljø. I fremstillingen af dragterne vægtes derfor ikke blot de visuelt synlige detaljer, men også de for publikum mere skjulte detaljer, som har betydning for aktørernes måde at bære dragten på og deres udførelse af de daglige handlinger. Det at udføre handlinger iført en 1800-tals dragt gør noget ved aktørens bevægelsesmønster og bidrager til fortolkningen af den historiske figur, som gestaltes (Egtved 2007). Hermed skal opbygningen af de historiske idealtyper ses som en betydningshandling, der ligger forud for mødet med publikum.

Idealtyperne kommer altså nærmest til at fremstå som fysiske rekonstruktioner, og de fremhæver fokus på rekonstruktionen som en fortolkning af faktisk fortid. Betydningsproduktionen omfatter således en henvisning til fortiden som reference, og betydningen er afhængig af, hvorvidt rekonstruktionen af det levede liv ligner det levede liv i den historiske fortid. Denne måde at forstå betydning på kan også genfindes i kritik af formidling i Den Gamle By. Dengang levende museum var et forholdsvist nyt begreb i museets formidlingsprogram, skrev antropolog Mads Daugbjerg følgende:

At fruen i Havbogade uddeler stegt flæsk og persillesovs til Gud og hvermand, kan næppe siges at være en 'autentisk' situation fra 1910, for slet ikke at tale om trommeslagerens annoncering af disse smagsprøver (Daugbjerg 2005:9). 
Hans undersøgelse tog udgangspunkt i forholdet mellem de institutionelle principper og den institutionelle praksis, hvor hans fokus problematiserer autenticitetsbegrebet som faglighed og den praksis, som knytter sig til aktørernes funktion som servicepersonel over for de besøgende. Hans kritik retter sig mod interaktionen mellem publikum og de gestaltede idealtyper. Som jeg ser det, giver han idealtyperne betydning alene med udgangspunkt i henvisningen til fortiden. Kritikken anfægter de gestaltede idealtypers autenticitetsværdi, når der interageres med publikum. Autenticitetsværdien, eller den værdi som knytter idealtyperne til fortid, udfordres, når der interageres med publikum. Værdikriterierne vægter, i hvilken grad det fremstillede "levede liv" ligner fortiden. Her træder altså den tilbagevendende kritik frem, som vedrører frilandsmuseernes manglende skelnen mellem fortid og historie. Med udsigelsesteoretiske begreber kan man her sige, at formidlingssituationen fortolkes således, at Den Gamle By fremstår som afsender og publikum som modtager. Interaktionen mellem publikum og formidler forstås at producere betydning på baggrund af henvisningens præmisser. Selvom publikum deltager ved at spørge og smage, indtager de en position, hvor de betragter en performativ handling, som de fortolker i forhold til den performative handlingsreference i fortiden. Ved at inddrage publikum svækkes denne værdi, idet de gestaltede idealtypers interaktion med publikum ikke længere forholder sig til det historiske ophav, men forholder sig til dagens krav fra museumsbesøgende. Jeg identificerer Daugbjergs problematisering som en anfægtelse af deltagelsesaspektet i betydningsproduktionen. I stedet for at acceptere at betydningsproduktionen alene skal forstås med udgangspunkt i kriterier for genkendelsen, ved at formidlingen søger at ligne den historiske fortid, vil jeg foreslå, at be- tydningsproduktionen også kan forklares med henblik på at skabe en effekt eller erfaring hos publikum.

Det er med denne hensigt jeg ser udsigelsesteorien som et anvendeligt redskab. Teorien gør det muligt at stille spørgsmålet: Hvad gør formidlingen? frem for hvad betyder formidlingen? Sidstnævnte spørgsmål indikerer, at betydning primært forstås som noget, der er uafhængig af det reelle møde mellem publikum og formidler, hvor det første spørgsmål fremhæver, at betydning også er afhængig af effekten af at deltage. Udsigelsesteorien kan altså bruges til at få øje på formidlingssituationens "gøren" frem for dens "væren".

\section{IDEALTYPERNE OG PUBLIKUMSDELTAGELSE}

Jeg vil nu demonstrere formidlingens "gøren" gennem min case fra skomagermadammen. Skomagermadammens problem med ilden danner udgangspunktet for en samtale, hvor publikums og skomagermadammens interaktion deler betydningsgivende ramme. Man kan sige, at problemet med ilden trækker publikum ind $\mathrm{i}$ handlingen på en måde, som kan svare til, at de får muligheden for at mærke historiens tekstur (jfr. Anderson 1986). Det bliver her publikums deltagelse i formidlerens handlinger, der tilsammen skaber betydningen. Måske kan man her tale om, at fokus flytter sig fra at genkende en performerende handling på baggrund af den historiske reference til fremstilling af betydningshandling? Publikum forholder sig til skomagermadammen som en person, der handler og agerer i et miljø. Frem for at være noget, der fortælles om, bliver hun fortællingens subjekt. Som fortælleinstans skaber skomagermadammen en specifik synsvinkel, hvorigennem "det levede liv" erfares.

I sådan en forskydning bliver det nødven- 
digt at skelne mellem formidlingens performancekarakter, altså at fremvise for andre, og formidlingens erfaringsdannende karakter, altså at erfare ved at udforske en anden virkelighed (Bolton 1984:124). Inden for dramateori skelnes der mellem performance, som den adfærd der fremvises for et publikum, og workshopindøvelse, hvor en aktør indøver bestemte adfærdssekvenser (Schechner 1985:80). Performance skal ikke forveksles med det udsigelsesteoretiske begreb performerende, som betegner den singulære udsigelse. Performance knytter sig snarere til bestemte kunstneriske og kommunikative udtryksformer, hvor fremvisning af adfærd er et centralt greb. Workshopbegrebet fremhæver læringsdimensionen i at skulle erfare en anden (eller andens) virkelighed. Indøvelsen er den proces, hvor adfærd fortolkes, indøves, redigeres og lades med betydning hos aktøren. Processen kan forklare, hvordan den historiske dokumentation fortolkes gennem kropslig udfoldelse. I workshopindøvelsen kan betydningsproduktionen med udsigelsesteoriens begreber udgøre den udsagte udsigelse. På baggrund af de historisk dokumenterede forhold fortolker aktøren adfærden som et spørgsmål om, hvad han/hun vil gøre, hvis (if) bestemte forhold var til stede? I workshopindøvelsen anvendes dette "hvis" som en måde, hvorpå givne omgivelser, affekter og vilkår undersøges kropsligt for senere at blive fikseret $i$ en performance tekst, der skal fremvises for andre.

Forskellen mellem workshopindøvelsen og performance ligger i, hvorvidt udøvelsen af adfærd er rettet mod et erfaringsbaseret fortolkningsformål (for aktøren) eller et fremvisningsformål (overfor publikum). De dramapædagogiske begreber kan anvendes i diskussionen om betydningsdannelse i dramatiseret museumsformidling, idet de kan bidrage til at nuancere forståelsen af handlingsfrem- stillingens ærinde. Gennem workshopindøvel123 sen og fortolkningsprocessen opnår aktøren en særlig viden, som kan betegnes som kropslig kundskab. Den amerikanske teaterforsker Richard Schechner skelner mellem performance og workshopindøvelse, når han beskriver begrebet "restaureret adfærd", hvor han vægter en aktørs adfærd som et produkt, der er bygget op gennem kropslig fortolkning af historisk kildemateriale. Adfærden får en værdi i kraft af at være en historisk fortolkning af et levet liv, som derefter fremvises for publikum. I denne beskrivelse af "restaureret adfærd" organiseres betydningsdannelsen med vægt på, at aktørerne fremviser for et betragtende publikum, og publikum fortolker aktørernes adfærd som kvalificeret bud på en fortolkning af levet liv i fortiden. Budskabets betydning ligger således fikseret i adfærden, som fremvises af aktørerne for publikum.

Det er nærliggende at fortolke formidlingssituationen i købmandsgården på en måde, som fremhæver adfærdens performance-karakter, begrundet ud fra den måde, hvorpå publikum stiller sig betragtende til aktørernes adfærd. De interagerer på en måde, som fremhæver, at deres egen og de gestaltede figurers deltagelse ikke deler betydningsrum. Med "betragtende" mener jeg her, at publikums egen deltagelse ikke får betydning på fortællingens handlingsniveau. Idet formidlingen alligevel involverer de besøgende gennem dialog og inddragelse i fortidens hverdagslige udfordringer, skabes et brud med fremstillingens betydning, hvis hensigten er, at betydning skal findes i genkendelsen af fortiden i formidlingssituationen som udtryk. Der skabes hermed et grundlag for at anfægte formidlingssituationen ud fra autenticitetsbegrebet, som Daugbjerg også er opmærksom på.

Formidlingssituationen hos skomagermadammen åbner for en anden måde, hvorpå 
124 betydningsproduktion kan forklares. Her skabes betydningen i højere grad gennem en interaktion med publikum, hvor den gestaltede idealtype og publikum deler betydningsrum. Jeg mener, at man kan forstå denne formidlingssituation med det dramapædagogiske begreb workshop, men hvor fortolkningsprocessen ikke alene knyttes til aktøren. Skomagermadammen skaber på baggrund af hendes problemer med at tænde ild rammer, som fungerer som vilkår for at leve i en tid uden elektricitet. Gennem hendes adfærd får publikum muligheden for at undersøge og erfare de konsekvenser, denne tids vilkår havde for menneskerne. De besøgendes egen deltagelse får betydning ved, at deres og skomagermadammens adfærd deler betydningsgivende kontekst. De besøgendes erfaringer får betydning ud fra spørgsmålet: "hvad ville du gøre, hvis bestemte vilkår var til stede?" Frem for at betragte aktørens fortolkning af adfærd som en performance/fremvisning inviteres publikum til at fortolke deres egen erfaring som følge af givne betingelser, altså en workshop, hvis vi låner Schechners begreb og anvender på det deltagende publikum. Handlingsforløbet, som det udfolder sig i formidlingssituationen, ændrer altså publikums deltagende status fra i udgangspunktet at betragte andres adfærd til at interagere i samme betydningsrum, som den adfærd, der bidrager til at gestalte idealfiguren og hendes hverdag. Deltagelsen foregår i rammen af historisk korrekte forhold, men fokus ligger på det deltagende publikums betydningsgivende bidrag til at skabe et fællesskab.

Museumsdirektør i Den Gamle By, Thomas Bloch Ravn, forklarer levende museum som et "supplement til den gængse, intellektuelt prægede museumsoplevelse med historiske oplevelser gennem sansepåvirkning og selvaktivitet" (Ravn 2008:15ff). Frem for at tale om et supplement vil jeg snarere anvende betegnel- sen synsvinkel eller erfaringsvinkel for at fremhæve, at der er tale om flere subjektive vinkler, der tilsammen bidrager til betydning gennem det at erfare historiens forskelligartede tekstur. Deltagelseskarakteren som betydningsbærende størrelse er afhængig af den måde, hvorpå den italesættes som fremvisningsformål eller erfaringsbaseret fortolkningsformål.

Synsvinklerne som betydningsskabende størrelser tilskriver jeg spørgsmålet om, hvordan museet etablerer relation mellem historien, altså den fortælling om fortiden som konstrueres, og publikums egen deltagelse og betydningsproduktion. Set i forhold til Bloch Ravns begreb ønsker jeg at fremhæve eller tydeliggøre, at historieformidling kan forstås ved at etablere flere mulige vinkler som tilgang til historien. Den måde hvorpå publikum forstår fortiden, vil bygge på forståelsen af en mere kompleks fortid.

\section{Deltagelse SOM LED I DEMOKRATISERING}

Jeg har i artiklen lokaliseret behovet for at udvikle begreber, som kan italesætte deltagelse på en ny måde. Deltagelse må forstås som del af formidlingsbudskabet, hvori værdien af at fremhæve et budskab med erfaringskarakter kan accepteres på linje med den værdi, som formidlingsbudskab med informativ karakter traditionelt er tilskrevet. Min erfaring er, at selv om det modtagerorienterede objektiv i dag har en stærk position hos museerne, så mangler der begreber, som kan fremhæve værdien af at skabe særlig effekt hos publikum på linje med værdier, som knytter fysiske genstande til fortiden eksempelvis gennem begrebet "autenticitet". Min påstand vil være, at forholdet mellem fortid og historie, som blev identificeret som frilandsmuseernes problem, i dag må betegnes som et begrebsmæssigt problem, som vedrører 


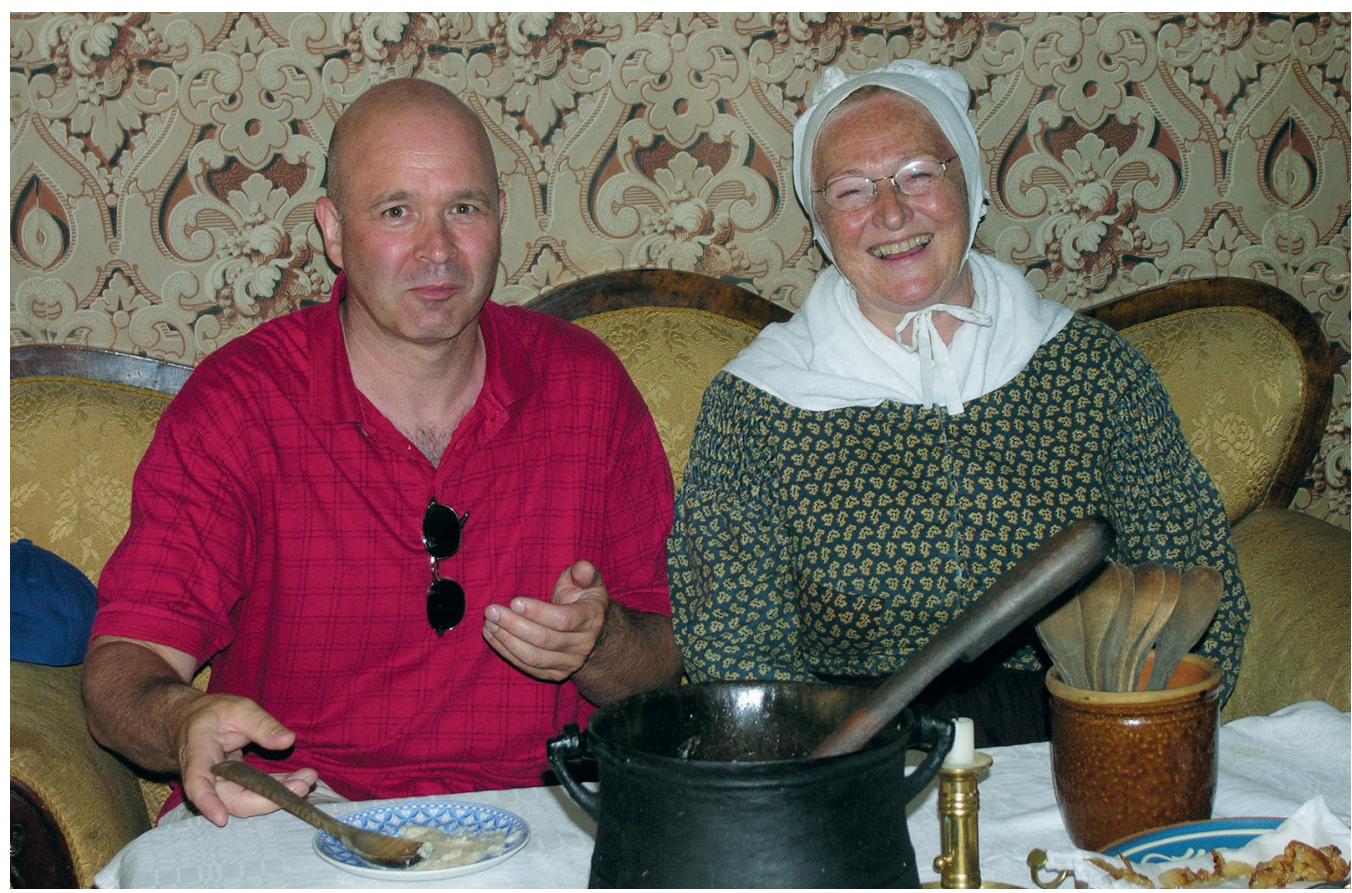

Fig. 5. Skomagermadammen med gest. Foto: Den Gamle By, 2008.

hele formidlingsområdet. Det er især det øgede fokus på publikumsdeltagelse og de mange forskellige former for publikumsdeltagelse, som skabes i praksis, der skaber behovet for en begrebsmæssig udvikling på området.

Hvorfor er det vigtig at gentænke vilkår for betydningsproduktion i forhold til publikumsdeltagelse? Publikumsdeltagelse er et fokus, som kan knyttes til et kulturpolitisk mål om at bidrage til øget demokratisering. Det indebærer blandt andet, at museernes opgave i samfundet ikke alene handler om at formidle historie, traditionelt set. Det handler også om, at museerne skal bidrage til, at borgerne udvikler evne til at stille spørgsmål og aktivt gå ind i diskussionen om, hvad vores historie er, og hvis historie der fortælles og viderebringes gennem generationer. Således kan man knytte deltagelsesspørgsmålet til et mere overordnet identitetsudviklende kulturpolitisk formål, hvor museernes opgave blandt andet bliver at vægte en facilitering af særligt designede erfaringsrum. Disse erfaringsrum leder publikum til at møde historien ved at stille spørgsmål til historien og til vores håndtering af den. Den form for dramatiserende museumsformidling, som jeg har beskrevet i artiklen, kan forklares som en metode, der imødekommer det mere overordnede projekt ved at facilitere publikums møde med historien - ikke som en lineær fortælling, men snarere som flere kontranarrativer, som inviterer publikum til at erfare flere perspektiver i historien, og den erfaring klæder dem på til at kunne stille spørgsmål. 


\section{SAMMENFATNING OG KONKLUSION}

I artiklen har jeg problematiseret levendegørelse som formidlingsform og publikumsdeltagelse som betydningsproduktion, når publikumsdeltagelse bliver en central del af budskabet. Jeg har fremlagt, hvordan deltagelsesaspektet ligger under for et tankesæt og for de begrebsmæssige værktøjer, som udspringer fra den traditionelle måde at formidle på. Artiklen foreslår, at deltagelsesaspektet anskues på baggrund af, hvorvidt formålet er at fremvise eller at skabe erfaringer, hvor det er afgørende at indtænke publikums rolle i forhold til formidlingsbudskabet.
Udfordringen med at knytte levendegørelse som formidlingsmetode til en accepteret håndtering af fortiden løses ikke nødvendigvis ved at se det levede liv som "et supplement" til historien om fortiden, som man kan se hos Den Gamle By. Artiklen foreslår i stedet at anse den singulære formidlingssituation som historieforståelse, der vægter, at der kan stilles en ny type spørgsmål til metode. Publikum kan gennem deltagelse erfare historiens tekstur og herigennem skabe et nyt grundlag for at engagere sig i den måde, hvorpå fortiden er del af nutiden. Der er i højere grad behov for at skabe accept omkring erfaringsdannelsen som del af formidlingsformålet. Tidligt i ar-

Fig. 6. Publikum gaester køkkenet i købmandsgården. Foto: Den Gamle By, 2007.

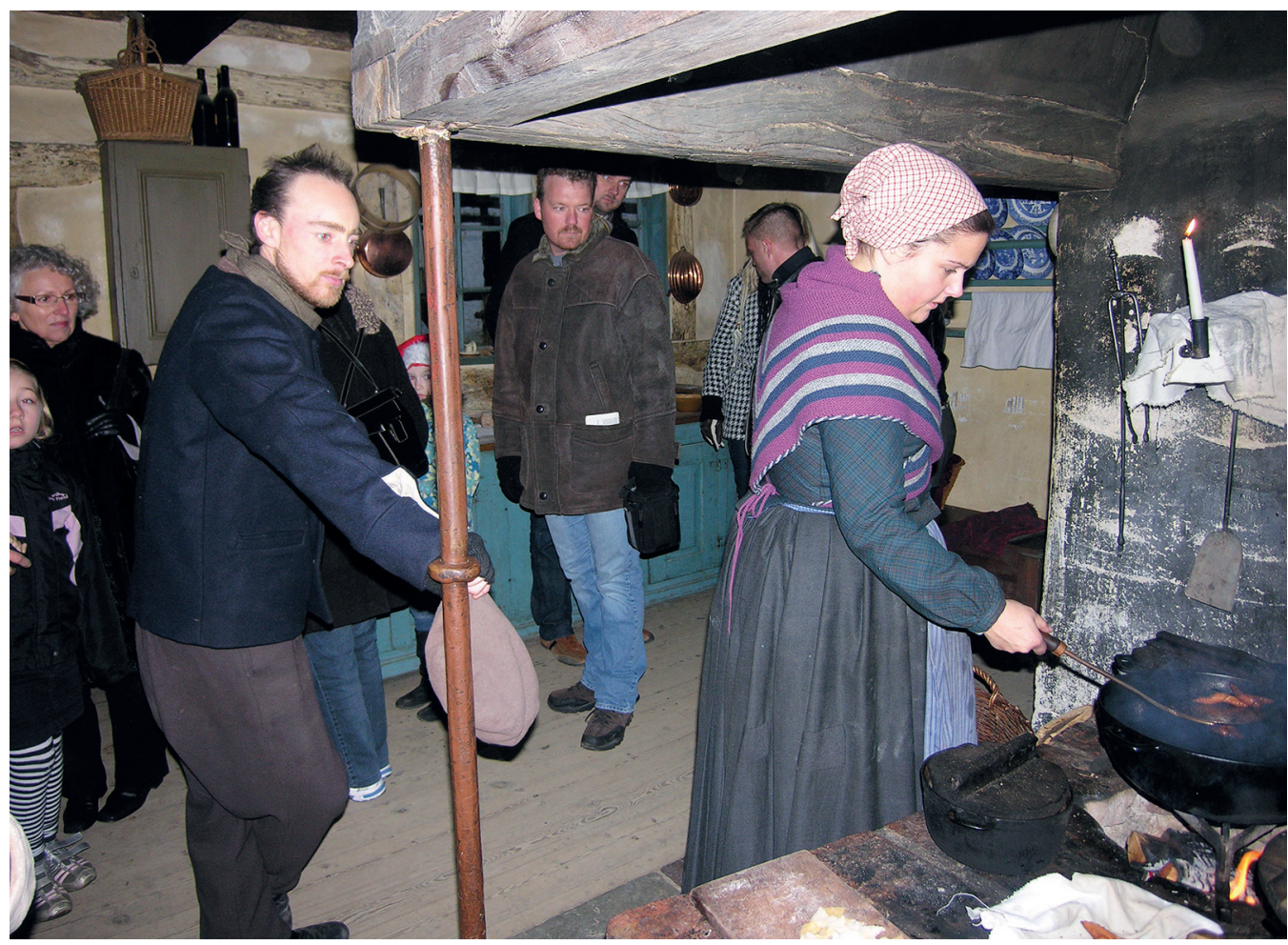


tiklen gjorde jeg opmærksom på, at museerne har gennemgået forandringer, når det gælder måder, hvorpå publikum indtænkes i forhold til formidlingsbudskabet. Det er min erfaring, at når publikums deltagelse får betydning i forhold til budskabet, så øger det behovet for, at museumsinstitutionen forholder sig til spørgsmålet om, hvordan budskabet skabes i formidlingssituationen. Betydningen som skabes i formidlingssituationen, hænger sammen med den måde, hvorpå publikums egen deltagelse får betydning.

\section{LITTERATUR}

Anderson, Jay 1986. Time Machine. The World of Living History. Nashville, Tennessee: The American Association for State and Local History.

Aremark, Anette Vandsø 2010. Musik og udsigelse. Ph.d. afhandling. Aarhus: Aarhus Universitet.

Bloch, Marc 1930/1993. "Om frilandsmuseer och bygdemuseer i Skandinavien 1930." Nordisk Museologi 1, 73-76.

Bolton, Gavin 1984. Drama as Education. An Argument for Placing Drama at the Centre of the Curriculum. London: Longman.

Brenna, Brita 1999. "Et sandt og levende bilde av verden. Verdensutstillinger og museumshistorie." Nordisk Museologi 1, 39-62.

Daugbjerg, Mads 2005. ”De gode gamle dage genoplivet. Frilandsmuseerne og spillet om fortiden." Nordisk Museologi 1, 3-14.

Goodacre, Beth \& Baldwin, Gavin 2002. Living the Past. Reconstruction, Re-enactment and Education at Museums and Historical Sites. London: Middlesex University Press.

Kyndrup, Morten 2003. Kunstvark og udsigelse. A.C.T.S. 18. Århus: Aarhus Universitet.

Maure, Marc 2004. ”Bønder, ånder, dukker og skuespillere i de første folkemuseene." Nordisk Museologi 1, 59-84.

Rasmussen, Holger 1993. "Hvorfor opstod folkemuseet? Var det Bernhard Olsens skyld eller

lå det i tiden?" Nordisk Museologi 2, 28-38.

Ravn, Thomas Bloch 2001. "Levende museum." Den

Gamle Bys Årbog. [Århus]: Den Gamle By.

Ravn, Thomas Bloch 2002. Den Gamle By. Et vindue til historien. København: Gyldendal.

Ravn, Thomas Bloch 2008. "Autenticitet og faglig troværdighed." Den Gamle Bys Årbog. [Århus]: Den Gamle By.

Rentzhog, Sten 2007. Friluftsmuseerna. En skandinavisk idé erövrar världen. Stockholm: Carlssons.

Schechner, Richard 1985. Between Theatre and Antropology. Philadelphia: University of Pennsylvania Press.

Skougaard, Mette 2005. ”Folkekulturen på museum." I Bruno Ingemann \& Ane Hejlskov Larsen. Ny dansk museologi. Århus: Aarhus Universitetsforlag.

Vatne, Ingrid 2013a. Dramatiseret museumsformidling, en undersøgelse af deltagelsesaspektet i formidling på frilandsmuseer og historiske centre. Ph.d. afhandling. Aarhus: Aarhus Universitet.

Vatne, Ingrid 2013b. Empiridel: Dramatiseret museumsformidling, en undersøgelse af deltagelsesaspektet i formidling på frilandsmuseer og historiske centre. Ph.d. afhandling. Aarhus: Aarhus Universitet.

Ingrid Vatne, ph.d, museumsinspektør iv@museumvestfyn.dk

\section{Museum Vestfyn}

Østergade $57 \mathrm{~A}$

DK-5610 Assens, Denmark 